\title{
Zona da Mata Mineira
}

\section{Wagner J. Amaral ${ }^{1}$}

Zona da Mata é mineira, o povo nobre, simples e guerreiro.

A região segue na batalha.

Morros e montes são bonitos, planícies, córregos, beira rio.

Oh! Sudeste encantado.

As gerais que é de Minas, o horizonte é belo, povo é hospitaleiro.

Deixo que vá embora contente e a porta vai ficar aberta acaso queira retornar.

Entre na casa da gente, tem chuveiro quente.

A cama de casal, deixo para você. Lhe ofereço bolo de milho, leite, queijo, rapadura e pinga.

Nosso café vem de colinas e das serras.

Uai, nós somos muito exigentes e pode contar com a gente no que der e vier.

Ao ir embora, tchau!

Não dou o adeus.

Tchau!

Vai com Deus, volte sempre!

Praias? Não temos praia,

Mas, sim, as cachoeiras, os córregos e as corredeiras!

São para refrescar você!

Uai, nós somos muito exigentes,

e pode contar com a gente, para o que der e vier.

Ao ir embora, tchau!

Não dou o adeus.

Tchau!

Vai com Deus, volte sempre!

${ }^{1}$ Graduado em Tecnologia em Gestão Ambiental da Universidade Federal de Viçosa - Campus Florestal. Condutor de Turismo em Unidade de Conservação pelo IFNMG - Campus Itamarandiba - MG. E-mail: wagner.j.amaral@ufv.br 